\title{
卫星遥感监测近 30 年来青藏高原湖泊变化
}

\author{
万玮 ${ }^{(1) 2}$, 肖鹏峰 ${ }^{\left(2^{*}\right.}$, 冯学智 ${ }^{(2)}$, 李晖 ${ }^{(2)}$, 马荣华 ${ }^{(3)}$, 段洪涛 ${ }^{(3)}$, 赵利民 ${ }^{(4)}$ \\ (1) 北京大学地球与空间科学学院, 北京 100871 ; \\ (2) 南京大学地理信息科学系, 南京 210023; \\ (3) 中国科学院南京地理与湖泊研究所, 湖泊与环境国家重点实验室, 南京 210008; \\ (4) 中国科学院遥感与数字地球研究所, 北京 100101 \\ * 联系人, E-mail: xiaopf@nju.edu.cn
}

2013-03-27 收稿, 2013-09-16 接受, 2014-01-22 网络版发表

全球变化研究国家重大科学研究计划(2011CB952001)、国家科技基础性工作专项(2006FY1106000)和遥感科学国家重点实验室开放基金 (OFSLRSS201112)资助

摘要 湖泊是揭示全球气候变化与区域响应的重要信息载体。以青海省、西藏自治区 2005 2006 年的 408 景 CBERS CCD 影像和 5 景 Landsat ETM+影像为主要数据源, 在 1975 年 前后的 1177 幅 1:10 万地形图和 82 幅 1:5 万地形图的支持下, 完成青藏高原 $1 \mathrm{~km}^{2}$ 以上湖泊的 卫星遥感调查, 并将其结果与 20 世纪 60 80 年代第一次全国湖泊调查进行比较, 对青藏高原湖 泊数量、面积、空间分布的变化情况进行分析. 确定截至 2005 2006 年, 青藏高原共有 $1 \mathrm{~km}^{2}$ 以上湖泊 1055 个, 占同期全国湖泊总数量的 $30 \%$ 以上，其中青海省 222 个，西藏自治区 833 个; 青藏高原湖泊总面积为 $41831.72 \mathrm{~km}^{2}$, 占全国湖泊总面积的 $50 \%$ 以上. 发现面积大于 $1 \mathrm{~km}^{2}$ 的 新生湖泊共 30 个, 原面积大于 $1 \mathrm{~km}^{2}$ 的湖泊消失 5 个. 13 个面积大于 $500 \mathrm{~km}^{2}$ 的大湖中, 羊卓 雍错在调查期内萎缩严重且目前仍在继续萎缩; 青海湖在调查期内总体呈萎缩状态, 但另有研 究表明自 2004 年后呈扩张趋势. 色林错、纳木错和赤布张错的面积也有较大的扩张. 新生湖泊 按照成因可归纳为河道扩展、沼泽转化等 6 种类型, 消亡湖泊则多是由于自然条件变化导致的 千涸. 在 3 个典型的气候与生态环境敏感区中, 那曲地区和可可西里地区的湖泊总体呈扩张趋 势, 而黄河源区的湖泊则总体呈萎缩状态. 区域湖泊变化特征是近几十年来青藏高原气候变化 导致的温度升高、冰川融化、冻土消融、雪线退缩等现象的显著响应. 调查和分析结论可为青 藏高原湖泊变化及其对气候波动的响应等研究提供参考.

关键词

青藏高原

湖泊调查

那曲地区

可可西里地区

黄河源区

气候变化
在全球气候变化的大背景下, 作为关注焦点区 域之一的青藏高原, 其环境变化对全球变化具有敏 感响应和强烈影响 ${ }^{[1,2]}$. 青藏高原气候变化不仅是全 球气候变化的重要部分, 而且对全球气候波动也可 能起到触发器和放大器的作用 ${ }^{[3,4]}$. 根据政府间气候 变化专门委员会(Intergovernmental Panel on Climate Change, IPCC)第四次气候变化评估报告及相关研究, 青藏高原近年来呈现气候变暖的整体趋势, 表现为
气温及地表温度升高、年降水量的区域性增加或减 少、冰川融化、冻土消融以及现代雪线退缩等 ${ }^{[5 ~ 8]}$. 因 此, 对于青藏高原气候环境变化的研究和评估, 正在 面临新的科学问题和挑战.

湖泊作为陆地水圈的组成部分, 参与自然界的 水分循环, 对气候的波动变化极为敏感, 是揭示全球 气候变化与区域响应的重要信息载体 ${ }^{[9,10]}$. 青藏高原 是地球上海拔最高、湖泊数量最多、湖泊面积最大的

引用格式: 万玮, 肖鹏峰, 冯学智, 等. 卫星遥感监测近 30 年来青藏高原湖泊变化. 科学通报, 2014, 59: 701-714

英文版见: Wan W, Xiao P F, Feng X Z, et al. Monitoring lake changes of Qinghai-Tibetan Plateau over the past 30 years using satellite remote sensing data. Chin Sci Bull, 2014, 59, doi: 10.1007/s11434-014-0128-6 
高原湖群区, 湖泊成因类型复杂多样, 对其湖泊数量 和面积变化进行监测, 是研究青藏高原气候环境变 化问题的一个必要组成部分, 能够为青藏高原冰冻 圈变化 ${ }^{[1]}$ 、能量水分循环 ${ }^{[2]} 、$ 生态系统变化 ${ }^{[11]}$ 等研究 提供重要的科学依据. 由于青藏高原气候环境条件 恶劣, 受自然因素制约, 难以用常规手段获取绝大多 数湖泊变化的数据, 借助卫星遥感监测和研究该区 湖泊状态及变化成为一种不可或缺的手段 ${ }^{[12,13]}$. 青 藏高原湖泊遥感研究涉及湖泊信息提取 ${ }^{[14]}$ 、湖泊水 位变化 ${ }^{[15]}$ 、区域性湖泊变化规律 ${ }^{[16]}$ 、长时序湖泊变 化特征 ${ }^{[12]}$ 、湖泊对气候变化的响应 ${ }^{[10]}$ 等诸多方面.

20 世纪 60 80 年代, 我国进行了第一次全国范 围的湖泊调查, 制成了 $1: 25$ 万全国湖泊分布图, 调 查成果编人 《中国湖泊志》 ${ }^{[9]}$ (以下简称《湖泊志》) 和《中国湖泊名称代码 (SL261:98)》 ${ }^{[17]}$ (以下简称《代 码本》)中. 根据该调查结果, 青藏高原面积在 $1 \mathrm{~km}^{2}$ 以上的湖泊共 1091 个, 总面积 $44993.3 \mathrm{~km}^{2}$, 约占全 国湖泊总面积的 49.5\%.2006 2009 年，国家科技基 础性工作专项“中国湖泊水质、水量与生物资源调查” 项目制订了《中国湖泊卫星遥感调查技术规程》(以 下简称《技术规程》), 以 2005 2006 年为调查基期, 利用卫星遥感技术第二次对全国湖泊进行了调查和 制图 ${ }^{[18,19]}$, 青藏高原湖区湖泊调查是其中的重要组 成部分, 本文对该调查结果进行报道, 给出截至 2005 2006 年青藏高原湖泊的数量、面积及空间分布 情况. 并将其结果与 20 世纪 60 80 年代第一次全国 湖泊调查进行比较, 对青藏高原湖泊的数量、面积变 化情况进行研究. 参考青藏高原气候、冰川、河流、 地质等相关资料, 以及本次调查后的相关研究成果, 对面积大于 $500 \mathrm{~km}^{2}$ 的大湖变化及其原因进行分析. 对本次调查中发现的 30 个新生湖泊、5 个消亡湖泊 的空间分布、类型及其成因进行初步分析. 重点针对 那曲地区、可可西里地区、黄河源区 3 个气候与生态 环境变化的敏感区域, 分析区域内湖泊变化规律及 其对青藏高原气候变化的响应. 本文的调查成果和 研究结论可为青藏高原的湖泊变化及其对气候波动 响应等研究提供参考.

\section{1 数据与方法}

以中巴地球资源卫星 CBERS CCD 影像(空间分 辨率 $19.5 \mathrm{~m}$, 卫星重访周期 $26 \mathrm{~d}$ ) 为主, Landsat ETM+ 影像(空间分辨率 $30 \mathrm{~m}$, 卫星重访周期 $16 \mathrm{~d}$ ) 作为补充
数据源. 同时, 考虑图像质量、云覆盖等问题, 辅以 2005 2006 年前后两年的数据, 且优先选择时间上与 调查基期最接近的数据. 对于极个别湖泊, 若仍未找 到符合条件的影像, 则将时间范围继续放宽, 但最早 不能低于 2000 年. 通过篮选, 保证每个湖泊丰水期 和枯水期各有一个时相的影像. 丰水期影像以 8,9月 为主, 邻近月份为辅; 枯水期影像以 4,5 月为主, 邻 近月份为辅. 通过对影像进行初步分析, 确定有湖泊 存在的影像共 413 景, 包括 408 景 CEBERS CCD 影 像(丰水期 205 景、枯水期 203 景)、 5 景 Landsat ETM+ 影像(丰水期 4 景、枯水期 1 景). 丰水期、枯水期遥 感影像覆盖情况分别如图 1(a), (b)所示. 根据遥感影 像几何精校正和湖泊变化检测的需要, 共收集整理 了 1975 年前后的 $1: 10$ 万地形图 1177 幅, $1: 5$ 万地形 图 82 幅, 主要集中在 $\mathrm{H} 45, \mathrm{H} 46$ 和 I 47 三个 $1: 100$ 万 地形图的图幅内. 地形图覆盖情况如图 1(c). 在遥感 解译的过程中, 还参考了第一次全国湖泊调查形成 的 $1: 25$ 万全国湖泊分布图、《湖泊志》、《代码本》、 《西藏河流与湖泊》 ${ }^{[20]}$ 、《西藏盐湖》 ${ }^{[21]}$ 、《青藏高

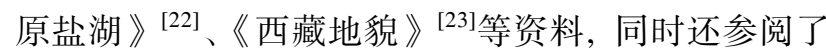
与青藏高原湖泊成因及特点 ${ }^{[24,25]}$ 、湖泊变化 ${ }^{[11,14,26]}$ 、 青藏高原水系特征 ${ }^{[27]}$ 等相关文献资料.

《技术规程》中规定了中国湖泊边界提取的基本 原则以及全国五大湖区 (蒙新湖区、青藏高原湖区、 东北平原与山区湖区、东部平原湖区、云贵高原湖区) 的次级原则, 同时还规定了湖泊数量、水面面积、湖 泊面积的确定方法以及湖泊命名规则, 具体已在文 献[18]中有详细的描述. 青藏高原的湖泊包括淡水 湖、咸水湖、盐湖(包括盐水湖、半干涸湖和干涸湖) 等多种类型，它们的大小、形状、色调，以及周围的 地形地貌和水系等宏观或微观特征在卫星遥感影像 上都存在很大差异. 因此, 对青藏高原湖泊进行调查 时, 还参考了各种类型湖泊的解译标志 ${ }^{[28]}$.

湖泊调查的技术流程主要包括数据预处理和影 像解译两个方面，具体阐述如下：(1) 纸质地形图扫 描图像几何校正, 按照 1:10 万标准地形图分幅设计 经纬网控制点, 并按照 $2 \mathrm{~km} \times 2 \mathrm{~km}$ 设计方里网控制 点, 基于此对纸质地形图的扫描图像进行几何校正, 每 $10 \mathrm{~km}$ 设置一个控制点, 每幅地形图的控制点不 少于 25 个, 校正均方根误差小于 $10 \mathrm{~m}$, 校正后的地 形图用于遥感影像的几何精校正; (2) 遥感影像几何 精校正, 选取道路交叉点、道路和河流的交叉点、地 

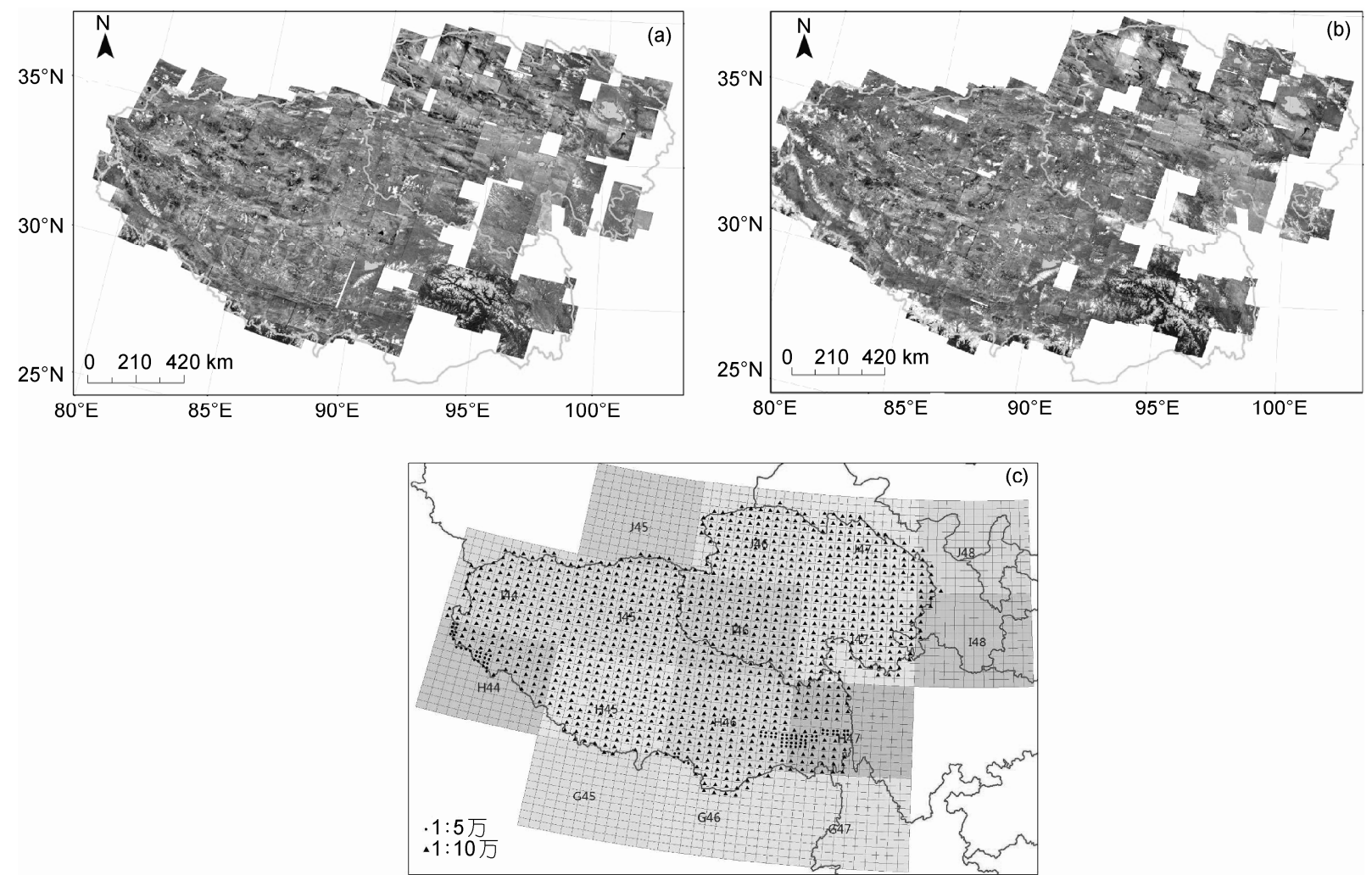

图 1 青藏高原湖区遥感影像与地形图覆盖情况

(a) 丰水期遥感影像; (b) 枯水期遥感影像; (c) 地形图

形特征点等同名点, 利用几何校正后的地形图对遥 感影像进行几何精校正, 每景影像不少于 20 个控制 点, 校正均方根误差控制在 $30 \mathrm{~m}$ 以内, 校正后的影 像统一采用以 Krasovsky_1940 为基准面的阿尔伯斯 圆锥等面积(Albers Conical Equal Area)投影, 未做正 射校正处理; (3) 遥感影像解译及湖泊边界确定, 利 用遥感影像提取水体的方法有多种，如单波段阈值 法 ${ }^{[29]}$ 、多波段指数法 ${ }^{[30]}$ 等, 在特定条件下可以达到较 好的精度. 但由于青藏高原湖泊种类繁多, 湖泊边界 的确定需要考虑色调、纹理、形状、地理位置、季节 变化等各种情况, 为严格控制提取精度, 直接采用人 工目视判读的方法对面积在 $1 \mathrm{~km}^{2}$ 以上的湖泊进行解 译. 对于湖泊边界的确定，一般以丰水期水边线作为 湖泊边界, 湖泊边界内的所有面积均算作湖泊面积 (包括水面面积、岛屿面积、围垦面积和滩地面积). 将 丰水期和枯水期的影像进行对照，对于有明显季节 性变化的湖泊或存在盐壳层的盐湖, 需结合地形图 确定季节性被水覆盖的滩地或盐壳层是否作为湖泊 的组成部分, 即如果滩地或盐壳层在两期影像中均
位于水边线外围, 则不作为湖泊的组成部分; 如果其 在一期影像上位于水边线外围，而在另一期影像上 位于水边线以内, 则以两期水边线的中心线作为湖 泊边界.

除调查正常湖泊外, 还确定了 2 类特殊湖泊, 即 新生湖泊和消亡湖泊, 其定义及判断标准见表 1 . 具 体方法为: 完成正常湖泊的解译后, 再对卫星遥感影 像进行逐景排查, 结合 $1: 25$ 万全国湖泊分布图、《湖 泊志》和《代码本》, 记录新生湖泊和消亡湖泊的数 量, 并根据遥感影像解译确定湖泊的面积.

\section{2 调查结果}

\section{1 湖泊数量}

根据本次调查结果，青藏高原湖区共有湖泊 1055 个, 占全国湖泊总数量的 $30 \%$ 以上 ${ }^{[18]}$, 其中青 海省 222 个, 西藏自治区 833 个. 表 2 列出了《湖泊 志》、《代码本》和本次调查中湖泊数量的详细比较. 《湖泊志》中记载的青藏高原 $1 \mathrm{~km}^{2}$ 以上湖泊共 1091 
表 1 新生、消亡湖泊的定义及判断标准 ${ }^{[18,19]}$

\begin{tabular}{cll}
\hline 类型 & \multicolumn{1}{c}{ 定义 } & \multicolumn{1}{c}{ 判断标准 } \\
\hline 新生湖泊 & 第一次全国湖泊调查时客观上不存在、后期经 & 《湖泊志》和《代码本》中未记录, 早期地形图中原位置是陆地或湿地等 \\
& 地表变化而发育形成的、符合本次调查条件的 & 非湖泊水体, 经多期卫星遥感影像和实地调查, 确实存在的符合本次调 \\
& 湖泊 & 查条件的湖泊 \\
消亡湖泊 & 第一次全国湖泊调查时客观存在, 按照本次 & 《湖泊志》或《代码本》中有记录, 早期地形图中记载原位置确实有湖泊 \\
& 调查的条件, 已经不存在的湖泊 & 存在, 经多期卫星遥感影像确认已经完全干涸且无湖泊痕迹、或尚有湖泊 \\
& & 边界但已全部被围乍、或因其他原因而消失的湖泊 \\
\hline
\end{tabular}

表 2 青藏高原湖泊数量统计和比较(个)

\begin{tabular}{|c|c|c|c|c|c|c|c|c|}
\hline 类型 & 省份 & $>1000 \mathrm{~km}^{2}$ & $500 \sim 1000 \mathrm{~km}^{2}$ & $100 \sim 500 \mathrm{~km}^{2}$ & $50 \sim 100 \mathrm{~km}^{2}$ & $10 \sim 50 \mathrm{~km}^{2}$ & $1 \sim 10 \mathrm{~km}^{2}$ & 合计 \\
\hline \multirow{3}{*}{$\begin{array}{l}\text { 湖 } \\
\text { 泊 } \\
\text { 志 }\end{array}$} & 青海 & 3 & 5 & 17 & 13 & 45 & 189 & 272 \\
\hline & 西藏 & 2 & 5 & 40 & 57 & 158 & 558 & 819 \\
\hline & 合计 & 5 & 10 & 57 & 70 & 203 & 745 & 1091 \\
\hline \multirow{3}{*}{$\begin{array}{l}\text { 代 } \\
\text { 码 } \\
\text { 本 }\end{array}$} & 青海 & 3 & 5 & 19 & 15 & 48 & 171 & 261 \\
\hline & 西藏 & 2 & 5 & 38 & 57 & 151 & 527 & 780 \\
\hline & 合计 & 5 & 10 & 57 & 72 & 199 & 698 & 1041 \\
\hline \multirow{3}{*}{$\begin{array}{l}\text { 本 } \\
\text { 次 } \\
\text { 调 } \\
\text { 查 }\end{array}$} & 青海 & 1 & 5 & 18 & 13 & 53 & 132 & 222 \\
\hline & 西藏 & 2 & 5 & 51 & 56 & 185 & 534 & 833 \\
\hline & 合计 & 3 & 10 & 69 & 69 & 238 & 666 & $1055^{\text {a) }}$ \\
\hline
\end{tabular}

a) 不包括 34 个在 1:25 万全国湖泊分布图上有记录且面积大于 $1 \mathrm{~km}^{2}$, 但在本次调查中测得面积小于 $1 \mathrm{~km}^{2}$ 的湖泊

个, 包括青海省 272 个, 西藏自治区 819 个. 《代码 本》中共 1041 个, 包括青海省 261 个, 西藏自治区 780 个. 需要说明的是：(1) 关于青海省 $1000 \mathrm{~km}^{2}$ 以 上的湖泊, 《湖泊志》和 《代码本》中记载的均为 3 个, 而本次调查中仅为 1 个, 缺少察尔汗盐湖和昆特 依干盐湖. 这是因为《湖泊志》中将达布逊湖、泳聂 湖、北霍布逊湖、南霍布逊湖等 10 个卤水湖统称为 察尔汗盐湖, 而本次调查将这些湖泊分别进行解译. 此外, 昆特依干盐湖实际上为湖泊退化后形成的干 盐滩, 因此未列人本次调查的范畴. (2) 面积在 500 1000 $\mathrm{km}^{2}$ 之间的湖泊中, 对于青海省境内的, 《湖泊志》中记载和本次调查中虽数量均为 5 个, 但 涵盖的湖泊并不完全相同. 《湖泊志》中记载的包括 鄂陵湖、哈拉湖、乌兰乌拉湖、扎陵湖和大浪滩干盐 湖, 而本次调查结果则不包括大浪滩干盐湖, 同时却 包括了赤布张错(《湖泊志》中记载面积为 $476.8 \mathrm{~km}^{2}$, 本次调查中则扩张为 $515.68 \mathrm{~km}^{2}$. 该湖跨越青海和西 藏, 为方便叙述, 本文统一将其归于青海省). 对于 西藏自治区境内的 5 个湖泊, 《湖泊志》中记载的与 本次调查相同, 均包括扎日楠木错、当惹雍错、羊卓 雍错、昂拉仁错和班公错(此处为全湖面积, 包括中 国境内和境外的全部面积).
表 3 列出了本次调查中青藏高原新生、消亡湖泊 的数量. 根据本次调查结果, 青藏高原共有新生湖泊 30 个, 其中青海省 8 个, 西藏自治区 22 个; 共有消 亡湖泊 5 个, 其中青海省 2 个, 西藏自治区 3 个. 此 外, 本次调查还发现了在第一次湖泊调查中未被《湖 泊志》收录, 但经 1975 年前后的地形图核实, 该位置 的确有湖泊存在且符合本次调查条件的湖泊共 73 个, 其中青海省 6 个, 西藏自治区 67 个.

\section{2 湖泊面积与空间分布}

表 4 列出了《湖泊志》《《代码本》和本次调查中 湖泊面积的详细比较, 其中《湖泊志》对 $1 \sim 10 \mathrm{~km}^{2}$ 的湖泊总面积未作统计. 根据本次调查结果，青藏高 原湖泊总面积为 $41831.72 \mathrm{~km}^{2}$, 占全国湖泊总面积的 $50 \%$ 以上. 其中, $10 \mathrm{~km}^{2}$ 以上的湖泊 $39778.59 \mathrm{~km}^{2}$, $1 \sim 10 \mathrm{~km}^{2}$ 的湖泊 $2053.13 \mathrm{~km}^{2}$. 新生湖泊总面积为 $202.63 \mathrm{~km}^{2}$; 对于 5 个消亡湖泊, 消亡前在早期地形 图上的总面积为 $7.16 \mathrm{~km}^{2}, 1: 25$ 万湖泊分布图上总面 积为 $5.85 \mathrm{~km}^{2}$.

根据调查结果, 图 2 给出了青藏高原 $1 \mathrm{~km}^{2}$ 以上 湖泊的空间分布. 该区共有 13 个 $500 \mathrm{~km}^{2}$ 以上的大湖, 包括青海省 6 个: 青海湖、鄂陵湖、哈拉湖、乌兰乌 
表 3 青藏高原新生、消亡湖泊的数量(个)

\begin{tabular}{cccc}
\hline 湖泊类型 & 省份 & $10 \sim 100 \mathrm{~km}^{2}$ 湖泊数量 & $1 \sim 10 \mathrm{~km}^{2}$ 湖泊数量 \\
\hline \multirow{2}{*}{ 新生湖泊 } & 青海 & 2 & 6 \\
& 西藏 & 3 & 30 \\
\hline \multirow{2}{*}{ 消亡湖泊 } & 青海 & 0 & 2 \\
& 西藏 & 0 & 3 \\
\hline
\end{tabular}

表 4 青藏高原湖泊面积统计和比较 ${ }^{\text {a) }}\left(\mathbf{k m}^{2}\right)$

\begin{tabular}{|c|c|c|c|c|}
\hline 类型 & 省份 & $>10 \mathrm{~km}^{2}$ 湖泊 & $1 \sim 10 \mathrm{~km}^{2}$ 湖泊 & 合计 \\
\hline \multirow{3}{*}{ 湖泊志 } & 青海 & 18940.1 & - & - \\
\hline & 西藏 & 17583.6 & - & - \\
\hline & 合计 & 36523.7 & - & - \\
\hline \multirow{3}{*}{ 代码本 } & 青海 & 19743 & 514 & 20257 \\
\hline & 西藏 & 23343.6 & 1583.5 & 24927.1 \\
\hline & 合计 & 43086.6 & 2097.5 & 45184.1 \\
\hline \multirow{3}{*}{ 本次调查 } & 青海 & 12796.97 & 417.90 & 13214.87 \\
\hline & 西藏 & 26981.62 & 1635.23 & 28616.85 \\
\hline & 合计 & 39778.59 & 2053.13 & 41831.72 \\
\hline
\end{tabular}

a) “-”表示无统计数据

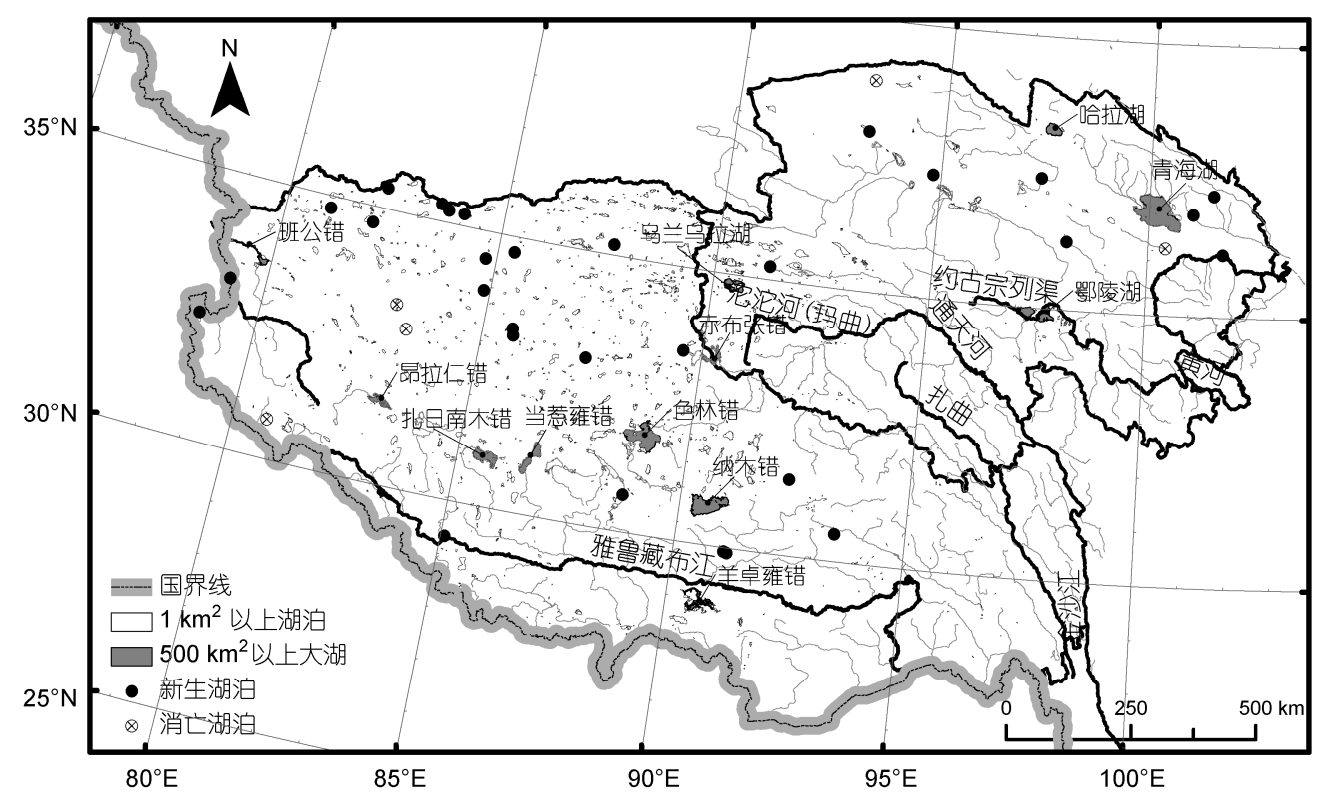

图 2 青藏高原 $1 \mathrm{~km}^{2}$ 以上湖泊、 $500 \mathrm{~km}^{2}$ 以上大湖、新生湖泊和消亡湖泊的空间分布

拉湖、扎陵湖和赤布张错; 西藏自治区 7 个: 色林错、 纳木错、扎日南木错、当惹雍错、羊卓雍错、班公错、 昂拉仁错. 冈底斯山北麓断陷带是大湖密集的区域, 形成了诸如纳木错、色林错等大型构造湖. 另外, 图 2 也给出了新生、消亡湖泊的空间分布，图中忽略其面 积, 分别用 2 种符号代表新生、消亡湖泊.

\section{3 分析与讨论}

\section{1 大湖面积变化及其原因}

青藏高原是全球气候变化的敏感区域，大湖面 积的变化在气候变化研究中最具价值. 首先分析调 查基期内 $500 \mathrm{~km}^{2}$ 以上的大湖面积的变化情况，结合 
自本次调查后至 2013 年的最新研究资料, 对大湖面 积的变化作进一步监测, 揭示影响湖泊面积变化的 因素. 表 5 给出了 13 个 $500 \mathrm{~km}^{2}$ 以上大湖的空间分布 及面积变化. 湖泊面积变动率利用公式 $\Delta t=\left(S_{\text {本次调查 }}-\right.$ $S$ (湖泊志》 $) / S$ (断泊志》 $) \times 100 \%$ 进行计算, 若 $\Delta t$ 为正, 将其称 为扩张率, 若为负, 则将其绝对值称为萎缩率.

(1) 面积萎缩的湖泊及原因分析: 30 年间所有大 湖中萎缩较为严重的为羊卓雍错和青海湖, 二者面 积分别减少了 184.82 和 $85.10 \mathrm{~km}^{2}$, 萎缩率分别为 $22.13 \%$ 和 $1.96 \%$. 此外哈拉湖和扎日南木错也存在较 小的萎缩. 羊卓雍错是雅鲁藏布江以南、喜马拉雅山 北麓最大的内陆湖泊, 为自成流域的封闭湖泊, 主要 靠地面径流和冰川融水补给. 不少研究与本次调查 基期基本一致，能够从不同侧面对该湖泊的变化给 出佐证. 文献[31 33]利用早期地形图、卫星遥感资 料、气象资料以及湖泊水文资料等, 对羊卓雍错水 位、面积变化及其对气候变化的响应做了详细分析, 根据其研究结论, 在降水增加、气温上升的情况下, 气温引起的湖泊蒸发效应超过降水增加导致的补给 影响, 是湖泊面积下降的主要原因. 在本次调查之 后, 又有一些研究给出了羊卓雍错的最新变化情

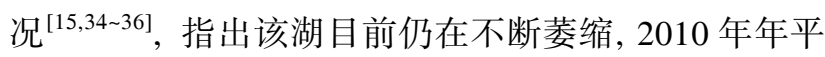
均水位达历史最低值 $16.25 \mathrm{~m}$, 截至 2010 年 4 月, 湖 泊面积已降至 $600.26 \mathrm{~km}^{2}$. 青海湖位于青海省东北部 的青海湖盆地内, 主要依赖地表径流和湖面降水补 给, 祁连山冰川是布哈河等其人湖河流的重要补给
源. 同期研究证实了本次调查的结果, 青海湖在调查 基期内湖泊面积呈萎缩趋势, 须指出的是, 这些研究 还证实自 2004 年后, 青海湖水位和面积均呈现缓慢 增加的趋势 ${ }^{[37,38]}$. 另有研究利用 2003 和 2009 年的 ICESat 高程数据, 也证实了青海湖的水位正以平均 $0.11 \mathrm{~m} \mathrm{a}^{-1}$ 的速率上升 ${ }^{[12]}$. 文献[39]则从气象学的角 度分析指出了青海湖流域夏季季风导致的降雨量增 加、蒸发量减少, 是青海湖水位上升的一个重要因素.

(2) 面积扩张的湖泊及原因分析：从表 5 可以看 出, 大湖中面积扩张的共有 7 个, 且分布于不同的区 域. 位于西藏那曲地区的色林错、纳木错和赤布张错 扩张十分明显, 扩张面积分别达 $501.02,79.40,38.88$ $\mathrm{km}^{2}$, 其中色林错扩张率高达 $30.78 \%$, 是 13 个大湖 中扩张最为显著的一个, 其面积已超过纳木错, 成为 西藏第一大湖, 另有研究结果也证实了这一点 ${ }^{[40]}$. 色林错位于冈底斯山北麓, 其最长的补给河流扎加 藏布发源于藏北的冰川山脉唐古拉、各拉丹冬等，因 此冰川变化与该湖面积变化存在密切关系. 对色林 错扩张原因的探究一直是近年来的研究热点, 多数 研究认为, 气温、地表温度升高导致冰雪融化和冻土 层变浅是湖泊扩张的主要原因 ${ }^{[41,42]}$. 此外, 湖泊北部 扩张最为显著, 这与湖泊北部各拉丹冬冰川面积萎 缩有直接关系 ${ }^{[16]}$, 对各拉丹冬地区冰川变化的研究 也有力地证明了这一结论 ${ }^{[43,44]}$. 截至 2010 年 10 月, 色林错湖泊面积已达 $2323.6 \mathrm{~km}^{2}$, 较本次调查的 $2129.02 \mathrm{~km}^{2}$ 又有了进一步扩张 ${ }^{[41]}$. 对纳木错流域冰

表 5 青藏高原 $500 \mathrm{~km}^{2}$ 以上大湖的面积变化

\begin{tabular}{|c|c|c|c|c|c|c|c|c|c|}
\hline $\begin{array}{l}\text { 湖泊 } \\
\text { 名称 }\end{array}$ & $\begin{array}{l}\text { 湖泊 } \\
\text { 代码 }\end{array}$ & 经度 $(\mathrm{E})$ & 纬度 $(\mathrm{N})$ & $\begin{array}{l}\text { 《湖泊志》记 } \\
\text { 载面积 }\left(\mathrm{km}^{2}\right)\end{array}$ & $\begin{array}{c}\text { 本次调查 } \\
\text { 丰水期水面面积 } \\
\left(\mathrm{km}^{2}\right)\end{array}$ & $\begin{array}{c}\text { 本次调查 } \\
\text { 枯水期水面面积 } \\
\left(\mathrm{km}^{2}\right)\end{array}$ & $\begin{array}{c}\text { 本次调查 } \\
\text { 湖泊面积 }\left(\mathrm{km}^{2}\right)\end{array}$ & $\begin{array}{l}\text { 变动 } \\
\text { 面积 } \\
\left(\mathrm{km}^{2}\right) \\
\end{array}$ & $\begin{array}{c}\begin{array}{c}\text { 面积 } \\
\text { 变动率 } \\
(\%)\end{array} \\
\end{array}$ \\
\hline 青海湖 & R63B002 & $100.19^{\circ}$ & $36.89^{\circ}$ & 4340.00 & 4232.32 & 4206.41 & 4254.90 & -85.10 & -1.96 \\
\hline 鄂陵湖 & D63A101 & $97.7^{\circ}$ & $34.9^{\circ}$ & 610.70 & 628.47 & 587.9 & 629.75 & 19.05 & 3.12 \\
\hline 哈拉湖 & R63F101 & $97.59^{\circ}$ & $38.29^{\circ}$ & 601.70 & 596.39 & 591.06 & 596.39 & -5.31 & -0.88 \\
\hline 乌兰乌拉湖 & S63B101 & $90.48^{\circ}$ & $34.81^{\circ}$ & 544.50 & 566.96 & 566.89 & 566.96 & 22.46 & 4.12 \\
\hline 扎陵湖 & D63A102 & $97.26^{\circ}$ & $34.93^{\circ}$ & 526.00 & 523.89 & 510.57 & 526.62 & 0.62 & 0.12 \\
\hline 赤布张错 & T63F201 & $90.26^{\circ}$ & $33.46^{\circ}$ & 476.80 & 515.68 & 514.33 & 515.68 & 38.88 & 8.15 \\
\hline 色林错 & T54B002 & $88.99^{\circ}$ & $31.81^{\circ}$ & 1628.00 & 2129.02 & 1965.26 & 2129.02 & 501.02 & 30.78 \\
\hline 纳木错 & T54B001 & $90.61^{\circ}$ & $30.74^{\circ}$ & 1961.50 & 2086.86 & 2023.38 & 2040.90 & 79.40 & 4.05 \\
\hline 扎日南木错 & T54B101 & $85.15^{\circ}$ & $30.99^{\circ}$ & 996.90 & 990.26 & 987.08 & 990.26 & -6.64 & -0.67 \\
\hline 当惹雍错 & T54B102 & $85.89^{\circ}$ & $31.23^{\circ}$ & 835.30 & 840.82 & 409.53 & 840.82 & 5.52 & 0.66 \\
\hline 羊卓雍错 & U54B101 & $90.71^{\circ}$ & $28.96^{\circ}$ & 835.30 & 620.78 & 620.98 & 650.48 & -184.82 & -22.13 \\
\hline 班公错 & T54B 103 & $79.25^{\circ}$ & $33.68^{\circ}$ & 604.00 & 626.01 & 641.75 & 627.19 & 23.19 & 3.84 \\
\hline 昂拉仁错 & T54B 104 & $81.24^{\circ}$ & $31.29^{\circ}$ & 512.70 & 507.53 & 556.86 & 542.89 & 30.19 & 5.89 \\
\hline
\end{tabular}


川、湖泊变化及其对气候变化响应的研究表明, 流域 东南部的念青唐古拉山现代冰川发育、气候变暖引起 的冰川融水增加是引起近年纳木错迅速扩张的主要 原因 ${ }^{[45,46]}$. 赤布张错原与西部的吐错连通, 后解体成 几个串珠状的湖泊 ${ }^{[47]}$, 湖水依赖冰川融水补给. 本 次调查中的湖泊扩张主要发生在与吐错相邻的位置, 这一结论与文献[8]一致, 扩张的因素主要归结于该 区冰川的萎缩. 色林错、纳木错和赤布张错的扩张在 一定程度上代表了那曲地区湖泊的整体变化趋势, 下文将对该区湖泊变化对气候变化的响应作进一步 分析. 本次调查发现, 黄河源头姊妹湖之一的鄂陵湖 面积扩张了 $19.05 \mathrm{~km}^{2}$, 与扎陵湖相比扩张更为明显. 文献[48]通过细致分析认为该湖泊在近 30 年实际上 经历了先萎缩后扩张的趋势, 另有文献则认为这种 转折是以 2000 年作为转折点, 2000 年后鄂陵湖水面 再次扩大的原因是鄂陵湖出水口处水电站建设导致 的湖泊水位抬升 ${ }^{[49]}$. 根据文献 [8], 乌兰乌拉湖在 1976 2000 年间面积缩小了 $59.8 \mathrm{~km}^{2}$, 文献[50]中推 测湖盆周围山地的降雪融水和泉水是该湖泊的主要 补给源, 因气候干燥导致的降水量小于湖盆蒸发量 是该湖萎缩的主要原因. 而截至本次调查的 2005 年 前后, 乌兰乌拉湖面积却扩张了 $22.46 \mathrm{~km}^{2}$. 此外, 根 据本次调查结果, 班公错和昂拉仁错的面积也存在
一定程度的扩张，且枯水期面积大于丰水期，但这与 现有的相关研究结论不一致. 因本研究未对调查时 段进行更细致的划分, 且未掌握 2005 年至今的湖泊 变化资料, 故暂不作讨论.

\section{2 新生、消亡湖泊类型及其成因}

湖泊的新生和消亡是青藏高原湖泊变化特征的 另一重要组成部分, 能够直观地反映特定区域内的 气候、河流、冰川、湖水盐分等的变化情况. 结合地 形、地貌、植被、河流、冰川等背景资料, 将本次调 查发现的 30 个新生湖泊按照成因分为 6 种类型, 即 (1) 类型一, 由河道扩展、河漫滩填充水体形成; (2) 类型二, 由沼泽转化形成; (3) 类型三, 由沙地、盐碱 地转化形成; (4) 类型四, 由戈壁转化形成; (5) 类型 五，冰川融水汇流于低地形成；(6) 类型六，季节性 湖泊, 丰水期水量较多, 枯水期则退化为盐壳.

各类型新生湖泊的空间分布如图 3 所示, 青海、 西藏的新生湖分别编号为 $\mathrm{Q} 01 \sim \mathrm{Q} 08$ 和 $\mathrm{X} 01 \sim \mathrm{X} 22$. 新 生湖泊一般面积较小, 面积最大的是位于海西蒙古 族藏族自治州的 $\mathrm{Q} 05$, 其面积为 $38.93 \mathrm{~km}^{2}$. 因此, 为 便于观察, 图 3 中忽略新生湖泊的形状和面积, 用不 同符号代表不同类型的新生湖泊. 图 4 分别给出了 6 种类型的新生湖泊示例, 早期地形图和调查期间的

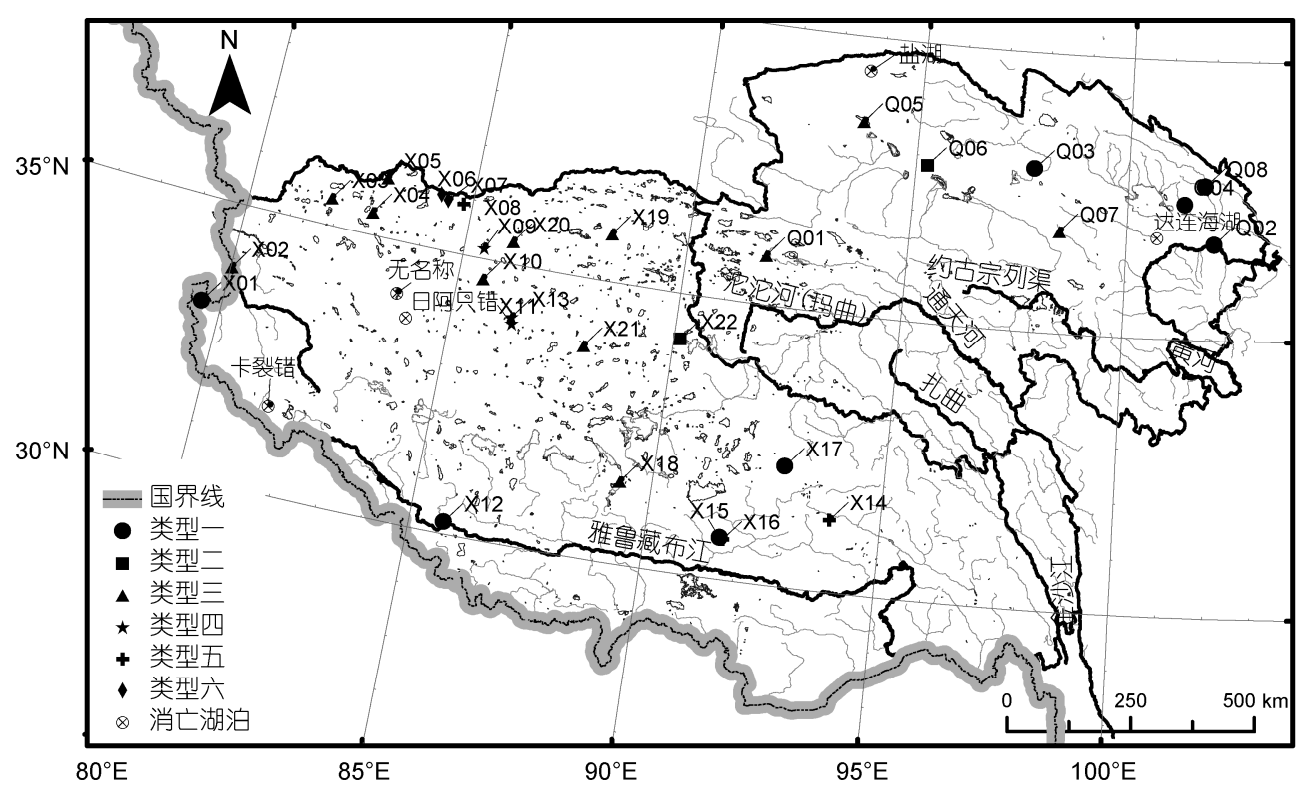

图 3 新生、消亡湖泊的空间分布

类型一, 河道扩展、河漫滩填充水体; 类型二, 沼泽转化; 类型三, 沙地、盐碱地转化; 类型四, 戈壁转化; 类型五, 冰川融水汇流; 类型六, 季节性湖泊 


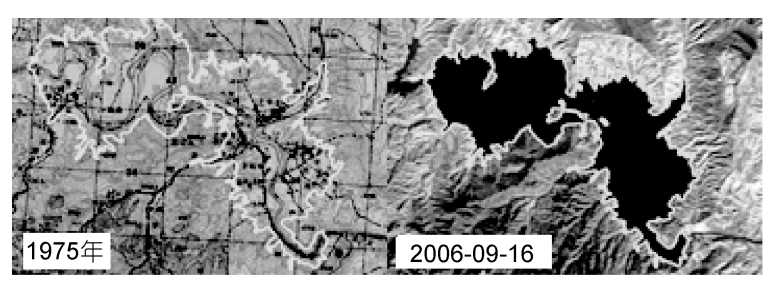

(a) 类型一: Q02

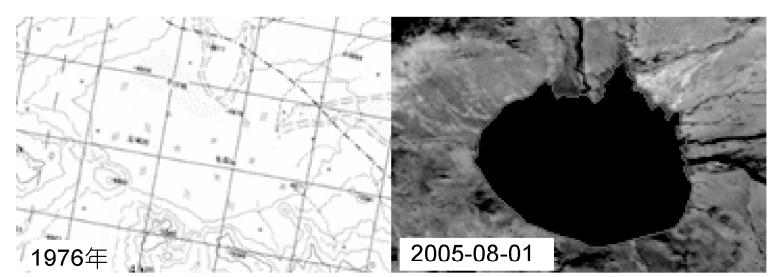

(c) 类型三: X10

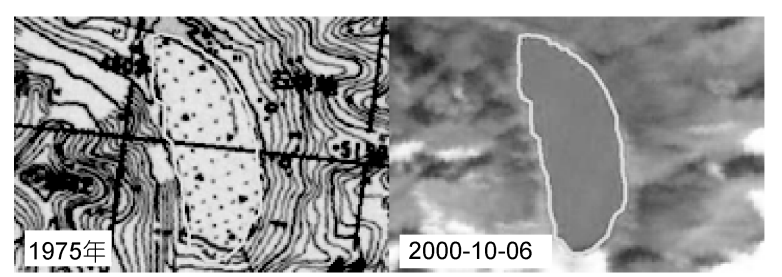

(e) 类型五: X14

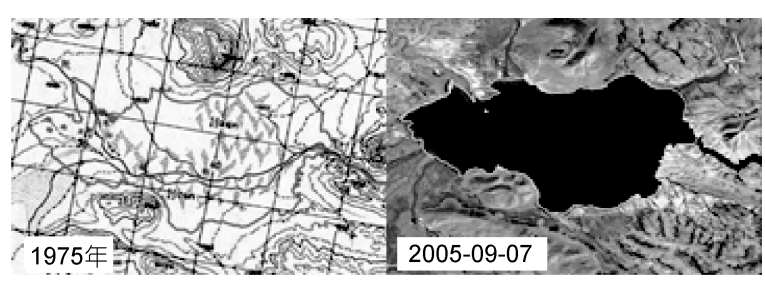

(b) 类型二: X22

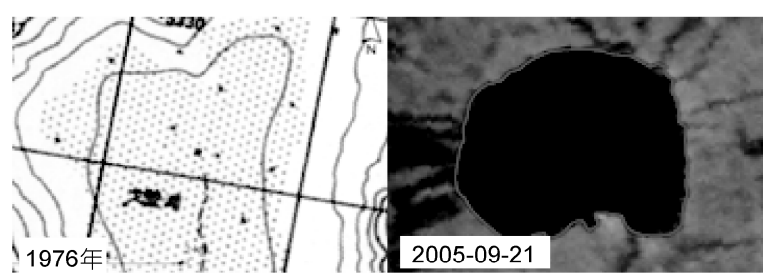

(d) 类型四: X11

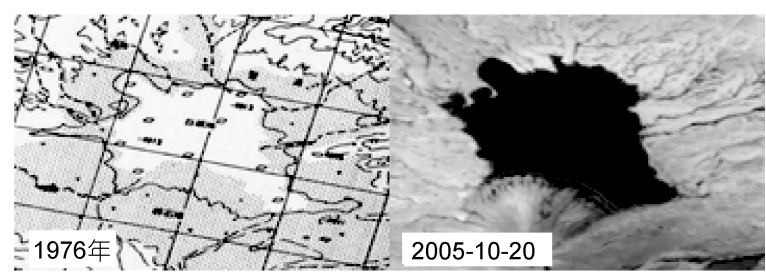

(f) 类型六: X07

图 4 不同类型的新生湖泊

(a) 河道扩展、河漫滩填充水体; (b) 沼泽转化; (c) 沙地、盐碱地转化; (d) 戈壁转化; (e) 冰川融水汇流; (f) 季节性湖泊

丰水期遥感影像直观地反映了新生湖泊的形成过程. 新生湖泊类型一多出现在大型江河及其支流的流经 途中; 类型二、五、六的湖泊成因也比较直观, 散落 分布于青藏高原各处, 但总体数量较少. 另需特别指 出的是, 若按常理推断, 由沙地、盐碱地或戈壁转化 成湖泊的可能性极小, 但根据本次调查结论, 在藏北 地区，却发现了不少这类新生湖泊(即类型三、四), 这种现象目前较难给出合理的解释, 初步判断可能 是早期地形图记录不准确所致.

图 3 同时也给出了调查发现的 5 个消亡湖泊的空 间分布情况, 包括青海省的盐湖、达连海湖, 西藏自 治区的日阿只错、卡裂错和一个无名湖泊. 根据遥感 影像和早期地形图判断(图 5), 除达连海湖是人为开 发导致的湖泊消失外, 其余 4 个湖泊均为湖水中盐分 蒸发导致的湖泊干涸. 总体来说, 青藏高原的湖泊人 为因素干预较少, 多是自然条件变化引起的湖泊自 然消亡.

\section{3 区域湖泊变化特征及其对气候变化的响应}

(i ) 那曲地区湖泊变化特征. 那曲地区是藏北
高原的主体部分, 位于可可西里、唐古拉山和冈底斯念青唐古拉山之间, 包括 11 个县, 平均海拔 $4500 \mathrm{~m}$ 以上, 整体地势西高东低, 现代冰川发育, 是世界上 海拔最高、面积最大的内流区. 该区大多数湖泊变化 主要受自然因素控制, 湖泊变化趋势能够很好地反 映气候变化, 也是青藏高原气候变化研究广泛关注 的区域之一.

图 6 给出了那曲地区 61 个 $30 \mathrm{~km}^{2}$ 以上湖泊的分 布及面积变化情况, 可以看出, 湖泊主要分布在尼 玛、班戈、申扎、安多和那曲县境内. 按照扩张率将 湖泊分为大于 $50 \%, 10 \%$ 50\%和小于 $10 \%$ 三个级别. 发现除有 3 个湖泊萎缩 (班戈错 $(-2.62 \%$ )、昂孜错 $(-3.47 \%)$ 和戈木错 $(-8.68 \%))$ 外, 其余湖泊均呈现不 同程度地扩张. 表 6 给出了扩张率大于 $50 \%$ 的湖泊情 况, 其中雅个冬错的扩张率高达 $179.93 \%$, 国加轮 曲、依布茶卡的扩张率也分别达到了 $90 \%$ 以上. 图 7 进一步给出了这 3 个湖泊在 1975 年地形图和 2005 年左右 CBERS 丰水期卫星影像上的对比情况. 雅个 冬错在 2005 年 9 月 7 日影像上显示湖泊西侧增加了 一大片水体, 这在早期地形图上是不存在的, 且湖泊 


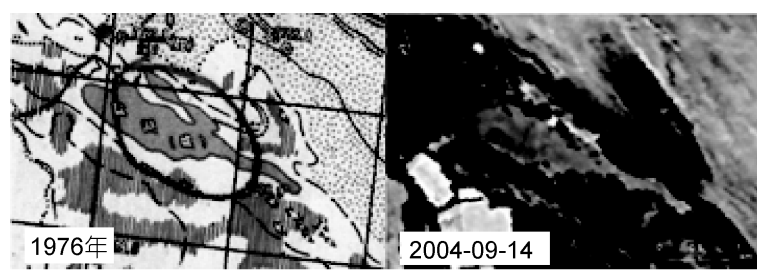

(a) 盐湖

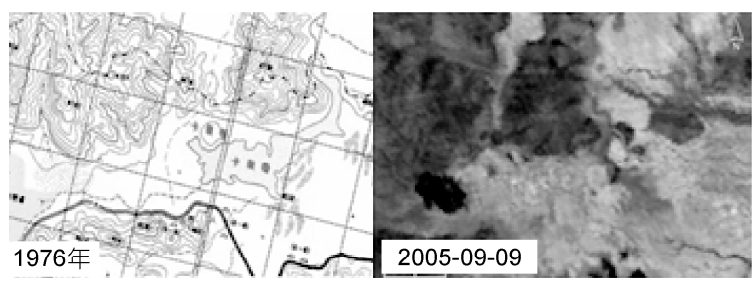

(c) 卡裂错

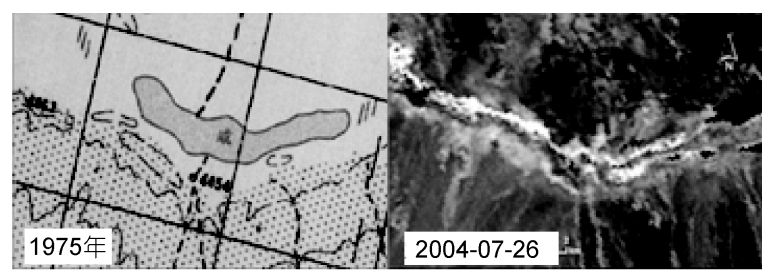

(b) 曰阿只错

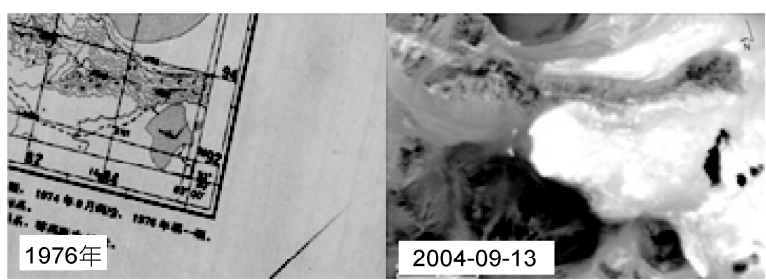

(d) 无名称

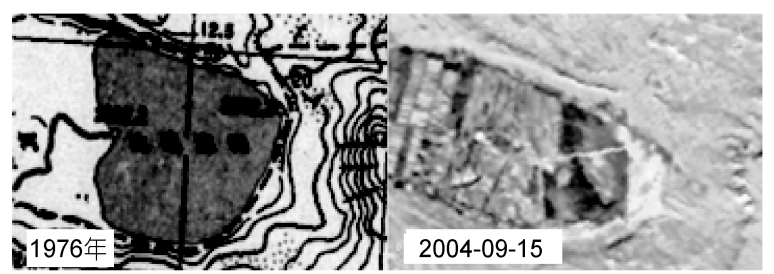

(e) 达连海湖

图 55 个消亡湖泊

(a) (d)均为湖水中盐分蒸发导致的湖泊干涸; (e)为人为开发导致的湖泊消失

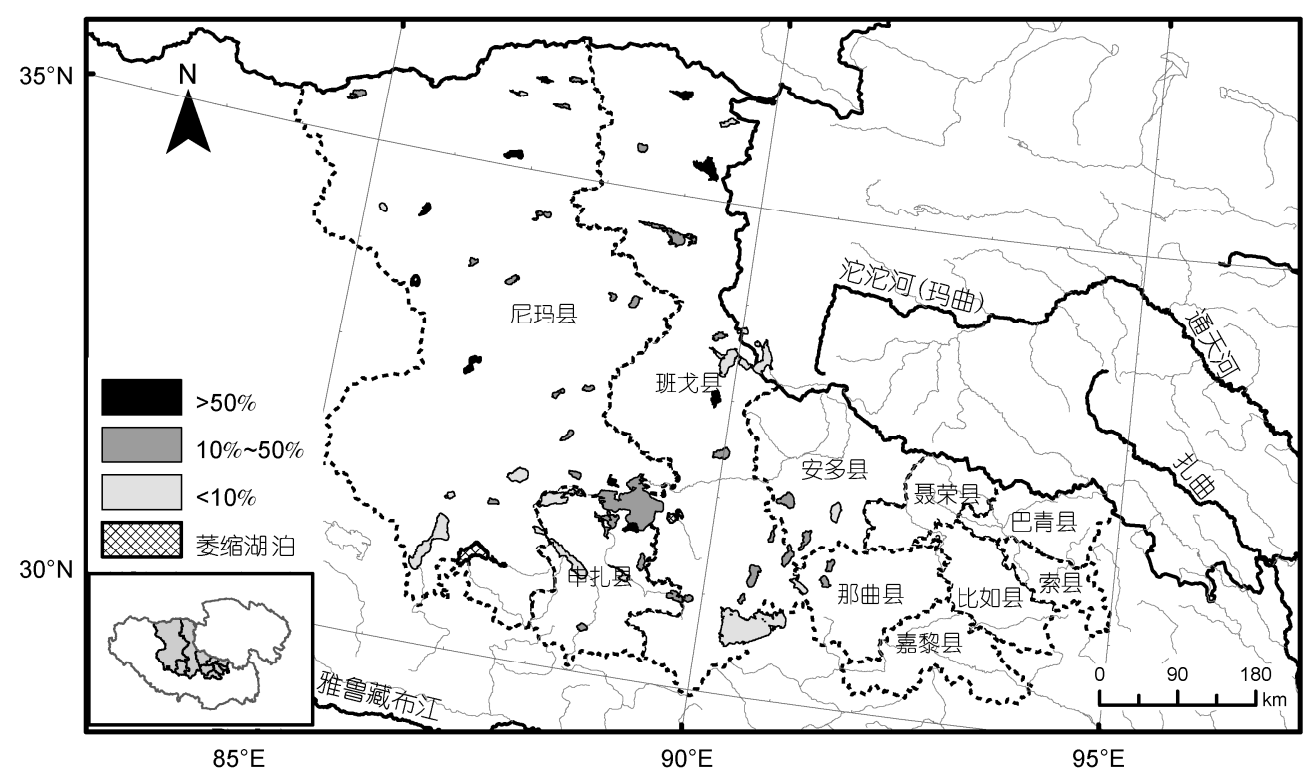

图 6 那曲地区 $30 \mathrm{~km}^{2}$ 以上湖泊的分布及其面积变化

东侧面积较地形图扩大了近 1 倍. 国加轮曲在早期地 形图上由几个小湖组成, 总面积不到 $2 \mathrm{~km}^{2}$, 但经 2005 年 9 月 7 日的卫星影像核实, 现在的国加轮曲面 积已扩大到 $69.26 \mathrm{~km}^{2}$, 地形图上原为沼泽的大面积
区域已经转化为湖泊. 与早期的地形图相比，依布茶 卡则是南部扩张较大，面积约扩大为原来的 2 倍.

(ii ) 可可西里地区湖泊变化特征. 可可西里位 于青藏高原北部，唐古拉山与昆仑山之间，是芫塘高 
表 6 那曲地区面积扩张率大于 $50 \%$ 的湖泊

\begin{tabular}{|c|c|c|c|c|c|c|c|}
\hline 湖泊名称 & 湖泊代码 & 经度 $(\mathrm{E})$ & 纬度(N) & $\begin{array}{c}\text { 《湖泊志》记载面积 } \\
\left(\mathrm{km}^{2}\right)\end{array}$ & $\begin{array}{c}\text { 本次调查面积 } \\
\left(\mathrm{km}^{2}\right)\end{array}$ & $\begin{array}{c}\text { 变动面积 } \\
\left(\mathrm{km}^{2}\right)\end{array}$ & $\begin{array}{c}\text { 面积变动率 } \\
(\%)\end{array}$ \\
\hline 雅个冬错 & T54D378 & $89.01^{\circ}$ & $31.56^{\circ}$ & 34.80 & 97.41 & 62.61 & 179.93 \\
\hline 国加轮曲 & T54F834 & $88.69^{\circ}$ & $31.99^{\circ}$ & 34.65 & 69.26 & 34.61 & 99.88 \\
\hline 依布茶卡 & T54D310 & $86.71^{\circ}$ & $32.93^{\circ}$ & 88.00 & 171.71 & 83.71 & 95.13 \\
\hline 玛尔盖茶卡 & T54D315 & $86.75^{\circ}$ & $35.12^{\circ}$ & 80.00 & 144.04 & 64.04 & 80.05 \\
\hline 雅根错 & T54D231 & $89.79^{\circ}$ & $33.01^{\circ}$ & 108.00 & 174.04 & 66.04 & 61.15 \\
\hline 多格错仁强错 & T54F215 & $89.24^{\circ}$ & $35.32^{\circ}$ & 207.50 & 328.84 & 121.34 & 58.48 \\
\hline 玉液湖 & S54F302 & $88.78^{\circ}$ & $36.01^{\circ}$ & 82.30 & 126.36 & 44.06 & 53.54 \\
\hline 振泉湖 & S54B306 & $86.96^{\circ}$ & $35.92^{\circ}$ & 42.40 & 64.75 & 22.35 & 52.72 \\
\hline 马而下错 & T54F328 & $84.52^{\circ}$ & $30.53^{\circ}$ & 63.80 & 96.46 & 32.66 & 51.19 \\
\hline 布若错 & T54F313 & $85.77^{\circ}$ & $34.40^{\circ}$ & 59.70 & 89.91 & 30.21 & 50.60 \\
\hline
\end{tabular}

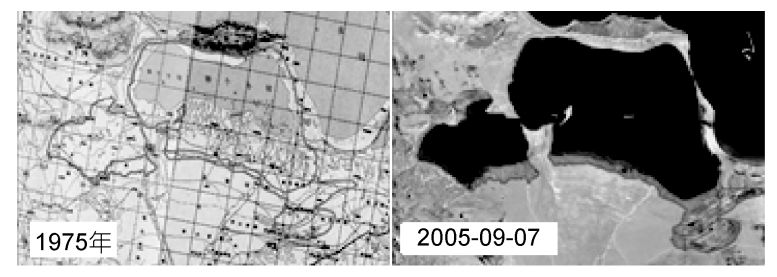

(a) 雅个冬错

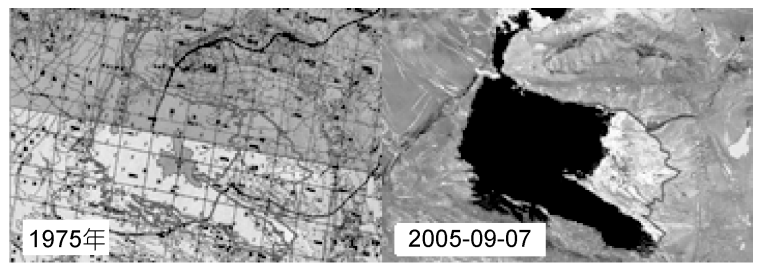

(b) 国加轮曲

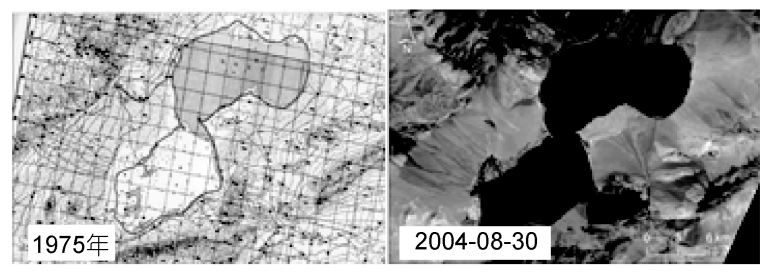

(c) 依布茶卡

图 7 雅个冬错(a)、国加轮曲(b)、依布茶卡(c) 湖泊扩张情况

其面积变动率分别高达 $179.93 \%, 99.88 \%$ 和 95.13\%

原内流湖区和长江北源水系交汇地区，可可西里国 家级自然保护区 $\left(89.25^{\circ} \sim 94.05^{\circ} \mathrm{E}, 34.19^{\circ} \sim 36.16^{\circ} \mathrm{N}\right)$ 是 目前世界上原始生态环境保存最完美的地区之一。 根据本次调查结果，对可可西里自然保护区 $10 \mathrm{~km}^{2}$ 以上湖泊的面积变化进行分析. 图 8 给出了这 35 个 湖泊的空间分布及面积变化情况，因上文对那曲地 区的讨论已涉及班戈县境内的湖泊，故此处不包括 这些湖泊. 与那曲地区相同, 仍按扩张率将湖泊分为 3 个级别. 可以看出，区域内除有 5 个湖泊呈萎缩趋 势 (明镜湖 $(-0.37 \%)$ 、移山湖 $(-2.89 \%)$ 、可考湖 $(-3.63 \%)$ 、特拉什湖 $(-5.46 \%)$ 和错达日玛 $(-5.90 \%))$ 外, 其余 30 个湖泊均呈现不同程度的扩张. 表 7 列出了 扩张率在 $10 \%$ 以上的湖泊, 其中无名称的湖泊以《代 码本》中的编码表示. 马鞍湖、小库赛湖、S63005 和涟湖的扩张率超过 $50 \%$.

（iii）黄河源区湖泊变化特征. 黄河发源于巴颜
喀拉山北麓的约古宗列盆地 ${ }^{[51]}$, 是我国重要的水源 涵养区，黄河源区位于青藏高原东南部，也是生态环 境极其敏感的区域。基于本次调查结果，分析 $99.40^{\circ} \sim 99.85^{\circ} \mathrm{E}, 34.20^{\circ} \sim 35.40^{\circ} \mathrm{N}$ 范围内面积大于 10 $\mathrm{km}^{2}$ 湖泊的变化情况. 如图 9 所示, 该区湖泊的整体 特点是面积小、数量多, 两个面积较大的湖泊扎陵 湖、鄂陵湖在前文已给出分析讨论，此处不再涉及. 在调查年段内, 黄河源区的湖泊整体上呈萎缩趋势, 萎缩率从 1\% 40\%不等. 表 8 列出了黄河源区萎缩率 大于 $10 \%$ 的湖泊.

(iv) 对气候变化的响应分析. 根据 IPCC 第二、 三次气候变化评估报告, 青藏高原温度和降水存在 不稳定的增加趋势，青藏高原在过去 50 年里升高了 $1.5^{\circ} \mathrm{C}^{[52,53]}$. IPCC 第四次评估报告显示, 青藏高原年 均温的升高速率为每 10 年 $0.16^{\circ} \mathrm{C}$, 降水量的增加主 要发生在高原东北部 ${ }^{[6]}$. 同时, 相关研究结论表明高 


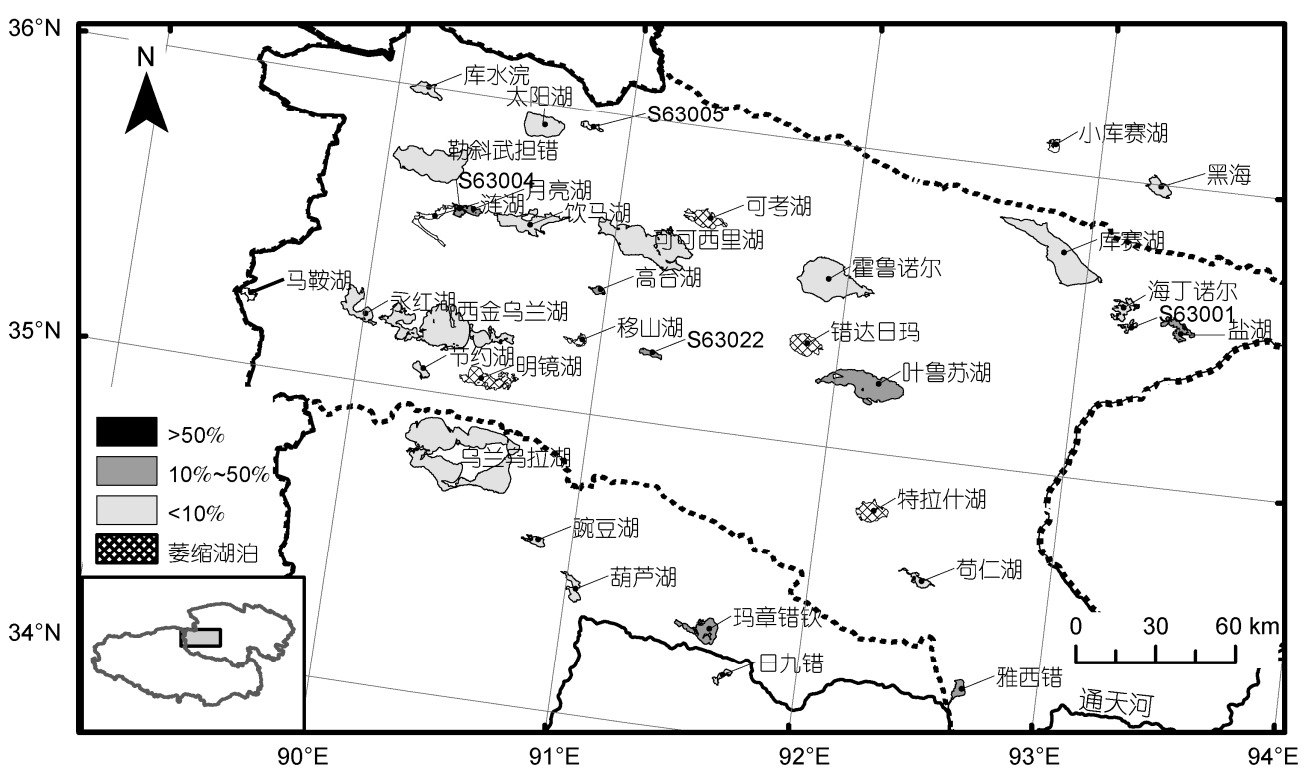

图 8 可可西里自然保护区 $10 \mathbf{~ k m}^{2}$ 以上湖泊的分布及其面积变化

表 7 可可西里自然保护区面积扩张率大于 $10 \%$ 的湖泊

\begin{tabular}{|c|c|c|c|c|c|c|c|}
\hline 湖泊名称 & 湖泊代码 & 经度(E) & 纬度 $(\mathrm{N})$ & $\begin{array}{c}\text { 《湖泊志》记载面积 } \\
\left(\mathrm{km}^{2}\right) \\
\end{array}$ & $\begin{array}{c}\text { 本次调查面积 } \\
\left(\mathrm{km}^{2}\right)\end{array}$ & $\begin{array}{c}\text { 变动面积 } \\
\left(\mathrm{km}^{2}\right)\end{array}$ & $\begin{array}{c}\text { 面积变动率 } \\
(\%) \\
\end{array}$ \\
\hline 马鞍湖 & S63F510 & $89.51^{\circ}$ & $35.23^{\circ}$ & 8.08 & 17.17 & 9.09 & 112.54 \\
\hline S63005 & S63F509 & $90.83^{\circ}$ & $35.95^{\circ}$ & 7.00 & 12.80 & 5.80 & 82.84 \\
\hline 小库赛湖 & R63F503 & $92.80^{\circ}$ & $36.09^{\circ}$ & 9.20 & 16.70 & 7.50 & 81.56 \\
\hline 涟湖 & S63B310 & $90.22^{\circ}$ & $35.56^{\circ}$ & 26.30 & 39.82 & 13.52 & 51.39 \\
\hline S63004 & S63F508 & $90.33^{\circ}$ & $35.60^{\circ}$ & 7.50 & 11.01 & 3.51 & 46.86 \\
\hline 叶鲁苏湖 & F63A201 & $92.13^{\circ}$ & $35.22^{\circ}$ & 144.10 & 204.92 & 60.82 & 42.21 \\
\hline S63022 & S63F534 & $91.21^{\circ}$ & $35.23^{\circ}$ & 12.57 & 16.83 & 4.26 & 33.90 \\
\hline 雅西错 & F63A303 & $92.68^{\circ}$ & $34.25^{\circ}$ & 19.30 & 25.02 & 5.72 & 29.65 \\
\hline 盐湖 & S63D308 & $93.41^{\circ}$ & $35.53^{\circ}$ & 32.80 & 41.55 & 8.75 & 26.67 \\
\hline 玛章错钦 & F63B301 & $91.59^{\circ}$ & $34.34^{\circ}$ & 58.80 & 73.44 & 14.64 & 24.90 \\
\hline 月亮湖 & S63F315 & $90.38^{\circ}$ & $35.61^{\circ}$ & 15.00 & 17.25 & 2.25 & 15.03 \\
\hline 高台湖 & S63F502 & $90.96^{\circ}$ & $35.41^{\circ}$ & 9.60 & 10.74 & 1.14 & 11.92 \\
\hline
\end{tabular}

原中部、东部和北部的气温和降水在近几十年来整体 呈增加趋势, 且降水增加多为气温升高所致 ${ }^{[1,54,55]}$. 文献[7]通过分析 1965 2000 年间多个气象站的降水 数据, 得出在这期间高原年降水量在西北部和中部 区域整体呈增加趋势，而在东北部则呈现减少的规 律, 本次调查期内青海湖面积减少是东北部降水减 少的直接响应, 而后湖泊面积的增加也响应了该区 降水又呈增加趋势这一规律. 另外, 从遥感观测的角 度, 气候变化的响应可以通过地表温度、冰川、雪线 等的变化来反映，相关研究结论已经反映了近几十 年来青藏高原地表温度升高、冰川消融、雪线退缩等
趋势 $[7,56,57]$.

通过前述分析可知，调查期内 3 个典型气候变化 敏感区域中, 那曲地区、可可西里地区的湖泊整体呈 扩张趋势，而黄河源区的湖泊则整体呈萎缩状态. 从 宏观来说, 这些现象充分揭示了湖泊变化对上述气 候变化特征的显著响应; 从微观来说, 其响应特征存 在区域和时间的差异. 具体分析如下: (1) 那曲地区, 与本次调查同期，文献[58]利用 1975 2005 年间的气 候资料，对那曲地区东南部湖泊扩张及其对气候变 化的响应进行了分析, 认为湖群面积扩张是对该区 气温上升、降水量增加、蒸发量减少、冰雪融水量增 


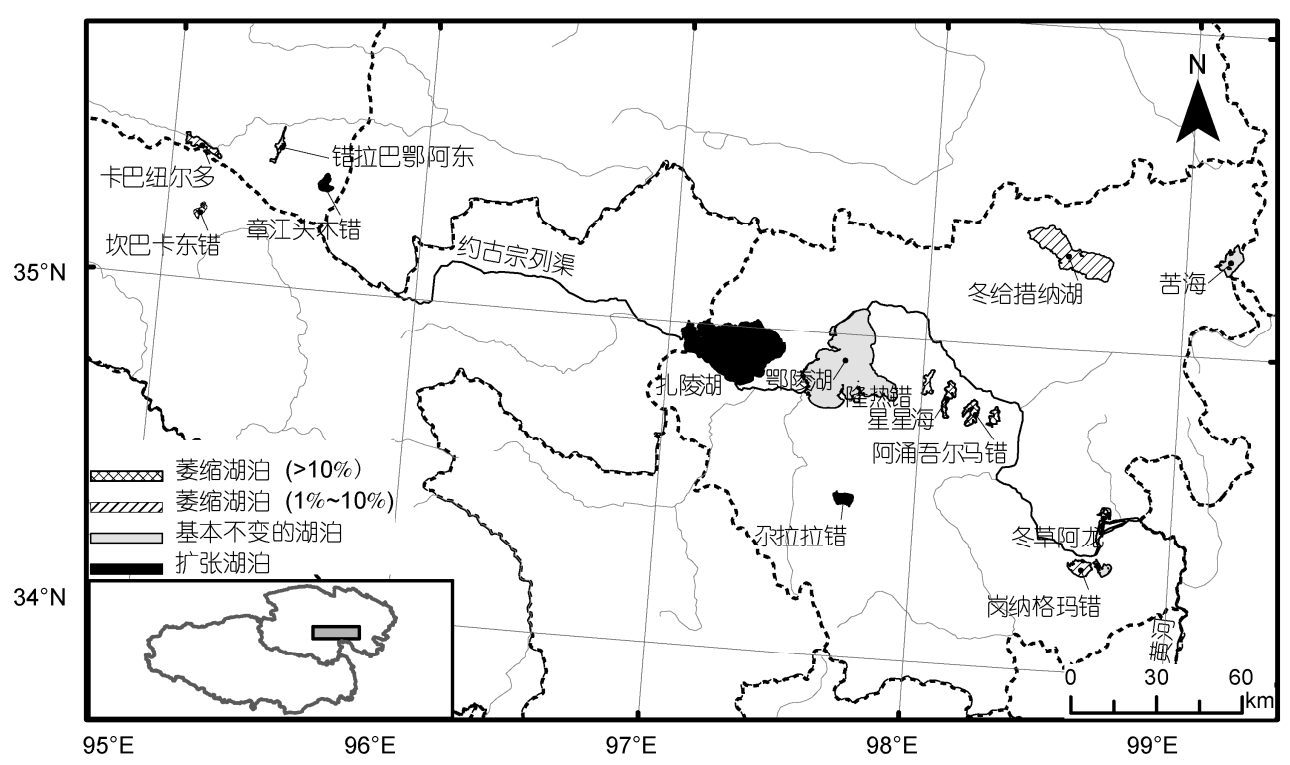

图 9 黄河源区 $10 \mathrm{~km}^{2}$ 以上湖泊的分布及其面积变化

表 8 黄河源区面积萎缩率大于 $10 \%$ 的湖泊

\begin{tabular}{lccccccc}
\hline \multicolumn{1}{c}{ 湖泊名称 } & 湖泊代码 & 经度 $(\mathrm{E})$ & 纬度 $(\mathrm{N})$ & $\begin{array}{c}\text { 《湖泊志》记载面积 } \\
\left(\mathrm{km}^{2}\right)\end{array}$ & $\begin{array}{c}\text { 本次调查面积 } \\
\left(\mathrm{km}^{2}\right)\end{array}$ & $\begin{array}{c}\text { 变动面积 } \\
\left(\mathrm{km}^{2}\right)\end{array}$ & $\begin{array}{c}\text { 面积变动率 } \\
(\%)\end{array}$ \\
\hline 坎巴卡东错 & $\mathrm{R} 63 \mathrm{~F} 315$ & $95.13^{\circ}$ & $35.21^{\circ}$ & 11.72 & 19.50 & -7.78 & -39.89 \\
阿涌尔马错 & $\mathrm{D} 63 \mathrm{~A} 305$ & $98.29^{\circ}$ & $34.78^{\circ}$ & 14.38 & 22.70 & -8.32 & -36.65 \\
章江头木错 & $\mathrm{D} 63 \mathrm{~B} 306$ & $95.61^{\circ}$ & $35.33^{\circ}$ & 13.72 & 20.00 & -6.28 & -31.38 \\
阿涌吾尔马错 & $\mathrm{D} 63 \mathrm{~A} 301$ & $98.20^{\circ}$ & $34.79^{\circ}$ & 27.17 & 37.60 & -10.43 & -27.73 \\
星星海 & $\mathrm{D} 63 \mathrm{~A} 303$ & $98.10^{\circ}$ & $34.83^{\circ}$ & 26.28 & 29.30 & -3.02 & -10.31 \\
\hline
\end{tabular}

加以及冻土退化等暖湿化气候变化特征的直接响应. 继本次调查之后, 一些最新的研究资料对截至 2010 2011 年那曲地区的湖泊变化进行了进一步探究, 得 到该区湖泊面积整体上仍呈现继续扩张的趋势, 这 一现象也很好地响应了高原中部和北部气温、降水、 冰川等的变化规律 ${ }^{[13,59,60]}$. (2) 可可西里地区, 大多 数依靠冰川融水、降水、河流补给的湖泊(如玛章错 钦、雅西错等)近 30 年来整体呈扩张趋势, 这是对青 藏高原北部降水量增多、昆仑山冰川融水增加的响 应 $^{[12]}$. 同时, 处于封闭湖盆内的咸水湖(如特拉什湖、 可考湖等)则由于气温的持续升高, 湖泊蒸发量大于 补给量, 造成湖泊萎缩 ${ }^{[50]}$. (3) 黄河源区, 近年来黄 河源区的生态环境持续恶化, 呈现蒸发量增加、径流 量减少、冰川后退、草地退化等现象 ${ }^{[61,62]}$. 本次调查 得出该区湖泊整体呈萎缩趋势, 是对该区气候和生 态环境恶化的有力指示, 另有同期研究也从不同侧 面揭示了该区湖泊对气候变化区域特征的响应 ${ }^{[63,64]}$.

\section{4 结论}

以 2005 2006 年的 CBERSCCD 和 Landsat ETM+ 卫星遥感影像为主要数据源, 并在 1975 年前后 1:10 万、 $1: 5$ 万地形图等资料的支持下, 对近 30 年来青藏 高原 $1 \mathrm{~km}^{2}$ 以上湖泊的数量、面积变化进行调查, 并 对湖泊变化规律、成因、对气候变化的响应等进行较 深人地分析和讨论. 得到的主要结论如下:

（1）利用卫星遥感技术能够成功地进行大范围 的湖泊现状调查和变化监测. 与实地调查相比, 利用 该手段开展调查研究既省时省力又不易遗漏湖泊的 细微变化. 特别对于青藏高原这类实地观测非常困 难，难以获得有效资料的区域，卫星遥感技术更体现 出独特的优势.

(2) 截至 2005 年左右, 青藏高原共有 $1 \mathrm{~km}^{2}$ 以上 湖泊 1055 个, 包括青海省的 222 个和西藏自治区的 833 个, 占同期全国湖泊总数量的 $30 \%$ 以上; 青藏高 原湖泊总面积为 $41831.72 \mathrm{~km}^{2}$, 占全国湖泊总面积的 
$50 \%$ 以上; 发现面积大于 $1 \mathrm{~km}^{2}$ 的新生湖泊共 30 个, 原面积大于 $1 \mathrm{~km}^{2}$ 的湖泊消失 5 个.

(3) 面积在 $500 \mathrm{~km}^{2}$ 以上的大湖中, 调查期年段 内羊卓雍错和青海湖萎缩严重, 目前羊卓雍错仍在 继续萎缩, 主要原因是气温升高引起的湖泊蒸发效 应超过降水补给(另有研究表明, 由于祁连山冰川融 化、降水增加等的影响, 自 2004 年后青海湖呈扩张 趋势). 那曲地区的色林错、纳木错和赤布张错面积 扩张较大, 气温和地表温度升高导致的冰川融水增 加是湖泊扩张的主要原因.

(4) 新生湖泊按照成因可以归纳为 6 种类型, 即
河道扩展、沼泽转化、沙地或盐碱地转化、戈壁转化、 冰川融水汇流以及季节性湖泊. 新生湖泊一般较小, 面积最大的不超过 $40 \mathrm{~km}^{2}$. 与新生湖泊相比, 消亡湖 泊数目相对较少, 且多是由于自然条件变化导致的 湖泊干涸.

(5) 在调查期内, 3 个典型气候与生态环境敏感 区域中, 那曲地区和可可西里地区的湖泊总体呈扩 张趋势, 是高原中北部因气候变暖导致的气温升高、 降水量增加、冰川融水增加等的直接响应. 黄河源区 的湖泊则总体呈萎缩状态，与该区气温升高导致蒸 发量持续增加、人湖河流的径流量减少等密切相关.

\section{参考文献}

1 Kang S, Xu Y, You Q, et al. Review of climate and cryospheric change in the Tibetan Plateau. Environ Res Lett, 2010, 5: 1-8

2 姚檀栋, 朱立平. 青藏高原环境变化对全球变化的响应及其适应对策. 地球科学进展, 2006, 21: 459-464

3 Alley R B, Meese D A, Shuman C A, et al. Abrupt increase in Greenland snow accumulation at the end of the Younger Dryas event. Nature, 1993, 362: 527-529

4 李潮流, 康世昌. 青藏高原不同时段气候变化的研究综述. 地理学报, 2006, 61: 327-335

5 Solomon S, Qin D, Manning M, et al. Climate Change 2007: The Physical Science Basis: Working Group I Contribution to the Fourth Assessment Report of the Intergovernmental Panel on Climate Change. Cambridge: Cambridge University Press, 2007

6 Parry M L, Canziani O F, Palutikof J P, et al. Climate Change 2007: Impacts, Adaptation and Vulnerability: Working Group II Contribution to the Fourth Assessment Report of the Intergovernmental Panel on Climate Change. Cambridge: Cambridge University Press, 2007

7 Zhao L, Ping C, Yang D, et al. Changes of climate and seasonally frozen ground over the past 30 years in Qinghai-Xizang (Tibetan) Plateau, China. Glob Planet Change, 2004, 43: 19-31

8 郡兆刚, 朱大岗, 孟宪刚, 等. 青藏高原近 25 年来主要湖泊变迁的特征. 地质通报, 2007, 26: 1635-1645

9 王苏民, 窦鸿身. 中国湖泊志. 北京: 科学出版社, 1989

10 Liu J S, Wang S Y, Yu S M, et al. Climate warming and growth of high-elevation inland lakes on the Tibetan Plateau. Glob Planet Change, 2009, 67: 209-217

11 鲁安新, 王丽红, 姚檀栋. 青藏高原湖泊现代变化遥感方法研究. 遥感技术与应用, 2006, 21: 173-177

12 Zhang G Q, Xie H J, Kang S C, et al. Monitoring lake level changes on the Tibetan Plateau using ICESat altimetry data (2003-2009). Remote Sens Environ, 2011, 115: 1733-1742

13 Song C, Huang B, Ke L. Modeling and analysis of lake water storage changes on the Tibetan Plateau using multi-mission satellite data. Remote Sens Environ, 2013, 135: 25-35

14 贾珅玥，肖鹏峰．基于多时相图谱的青藏高原湖泊变化检测研究. 国土资源遥感, 2009, 82: 78-81, 85

15 除多, 普穷, 旺堆, 等. 1974 2009 年西藏羊卓雍错湖泊水位变化分析. 山地学报, 2012,30: 239-247

16 万玮, 肖鹏峰, 冯学智, 等. 近 30 年来青藏高原芫塘地区东南部湖泊变化遥感分析. 湖泊科学, 2010, 22: 874-881

17 中华人民共和国水利部．中国湖泊名称代码(SL261-98). 中华人民共和国行业标准, 1998

18 马荣华, 杨桂山, 段洪涛, 等. 中国湖泊的数量、面积与空间分布. 中国科学: 地球科学, 2011, 4: 394-401

19 Ma R H, Duan H T, Hu C M, et al. A half-century of changes in China's lakes: Global warming or human influence? Geophys Res Lett, 2010, 37: L24106, doi: 10.1029/2010GL045514

20 中国科学院青藏高原综合科学考察队. 西藏河流与湖泊. 北京: 科学出版社, 1984

21 郑喜玉. 西藏盐湖. 北京: 科学出版社, 1988

22 郑绵平, 向军. 青藏高原盐湖. 北京: 科学技术出版社, 1989

23 中国科学院青藏高原综合科学考察队. 西藏地貌. 北京: 科学出版社, 1983 


\section{Climate Change. Cambridge: Cambridge University Press, 1995}

53 II to the Third Assessment Report of the Intergovernmental Panel on Climate Change. Cambridge: Cambridge University Press, 2001

54 刘禹, 安芷生, 马海州, 等. 青海都兰地区公元 850 年以来树轮记录的降水变化及其与北半球气温的联系. 中国科学 D 辑: 地球科 学, 2006, 36: 461-471

55 You Q L, Kang S C, Aguilar E, et al. Changes in daily climate extremes in the eastern and central Tibetan Plateau during 1961-2005. J Geophys Res, 2008, 113: 1-17

李炳元，王苏民，朱立平，等. $12 \mathrm{ka} \mathrm{BP}$ 前后青藏高原湖泊环境. 中国科学 D 辑：地球科学, 2001, 31: 258-263

施雅风，李吉均，李炳元，等. 晚新生代青藏高原的隆升与东亚环境变化. 地理学报, 1999, 54: 12-22

姜加虎，黄群. 青藏高原湖泊分布特征及与全国湖泊比较. 水资源保护, 2004, 6: 24-27, 70

曹建廷，秦大河，康尔泗，等. 青藏高原外流区主要河流的径流变化. 科学通报, 2005, 50: 2403-2408

王跃峰，肖抒，曾涛。西藏湖泊 TM 影像遥感分析。西藏科技, 2005, 5: 23-26 area. Water Resour Bull, 1987, 23: 493-508

Feng L, Hu C M, Chen X L, et al. Assessment of inundation changes of Poyang Lake using MODIS observations between 2000 and 2010. Remote Sens Environ, 2012, 121: 80-92

拉巴，德吉央宗，次珍，等. 基于 MODIS 影像的西藏羊卓雍湖面积变化与成因分析. 高原山地气象研究, 2011, 31: 66-68

除多, 普穷, 旺堆, 等. 西藏羊卓雍错湖面遥感监测模型及近期变化. 冰川冻土, 2012, 34: 530-536

巴卓玛，次珍，拉巴。羊卓雍错流域在 1971 2009 年期间的气候变化特征分析. 西藏大学学报(自然科学版), 2012, 27: 15-19

云，李栋梁，安迪. 青海湖水位变化对青藏高原气候变化的响应. 高原气象, 2012, 31: 57-64

Resource and Environmental Protection (ISWREP), 2011. 446-449

Qinghai-Tibetan Plateau) and possible forcing mechanisms. Holocene, 2010, 21: 297-304

边多, 边巴次仁, 拉巴, 等. 1975 2008 年西藏色林错湖面变化对气候变化的响应. 地理学报, 2010, 65: 313-319

拉巴，陈涛，拉巴卓玛，等. 基于 MODIS 影像的色林错湖面积变化及成因. 气象与环境学报, 2011, 27: 69-72

孟恺，石许华，王二七，等. 青藏高原中部色林错湖近 10 年来湖面急剧上涨与冰川消融. 科学通报, 2012, 57: 571-579

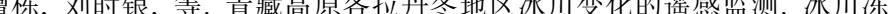

陈锋, 康世昌, 张拥军, 等. 纳木错流域冰川和湖泊变化对气候变化的响应. 山地学报, 2009, 27: 641-647

张博, 秦其明, 孙永军. 扎陵湖鄂陵湖近三十年变化的遥感监测与分析. 测绘科学, 2010, 35: 54-56

鲁萍丽. 青海可可西里地区湖泊变化的遥感研究. 硕士学位论文. 北京：中国地质大学, 2006

马永忠, 杨改河, 杨世琦, 等. 江河源区地域界定研究. 西北农林科技大学学报(自然科学版), 2004, 32: 11-14

Wang B, Bao Q, Hoskins B, et al. Tibetan Plateau warming and precipitation changes in East Asia. Geophys Res Lett, 2008, 35: 1-5

Salama M S, Van der Velde R, Zhong L, et al. Decadal variations of land surface temperature anomalies observed over the Tibetan Plateau by the Special Sensor Microwave Imager (SSM/I) from 1987 to 2008. Clim Change, 2012, 114: 769-781

边多, 杨志刚, 李林, 等. 近 30 年来西藏那曲地区湖泊变化对气候波动的响应. 地理学报, 2006, 61: 510-518

林乃峰, 沈渭寿, 张慧, 等. 近 35 a 西藏那曲地区湖泊动态遥感与气候因素关联度分析. 生态与农村环境学报, 2012, 28: 231-237

黄卫东, 廖静娟, 沈国状. 近 40 年西藏那曲南部湖泊变化及其成因探讨. 国土资源遥感, 2012,3:122-128

李林, 吴素霞, 朱西德, 等. 21 世纪以来黄河源区高原湖泊群对气候变化的响应. 自然资源学报, 2008, 23: 245-253

张士锋, 贾绍凤, 刘昌明, 等. 黄河源区水循环变化规律及其影响. 中国科学 E 辑: 技术科学, 2004, 34(增刊): 117-125

赵静, 姜琦刚, 陈凤臻, 等. 青藏三江源区蒸发量遥感估算及对湖泊湿地的响应. 吉林大学学报(地球科学版), 2009, 39: 507-513

张永勇, 张士锋, 翟晓燕, 等. 三江源区径流演变及其对气候变化的响应. 地理学报, 2012, 67: 71-82 